\title{
The UNAM-droplet freezing assay: An evaluation of the ice nucleating capacity of the sea-surface microlayer and surface mixed layer in tropical and subpolar waters
}

\author{
Luis A. LADINO ${ }^{1 *}$, Javier JUARÉZ-PÉREZ ${ }^{1}$, Zyanya RAMÍREZ-DÍAZ ${ }^{1,2}$, Lisa A. MILLER ${ }^{3}$, Jorge HERRERA ${ }^{4}$, \\ Graciela B. RAGA ${ }^{1}$, Kyle G. SIMPSON ${ }^{3}$, Giuliana CRUZ ${ }^{3}$, Diana L. PEREIRA ${ }^{1}$ and Fernanda CÓRDOBA ${ }^{1}$ \\ ${ }^{1}$ Instituto de Ciencias de la Atmósfera y Cambio Climático, Universidad Nacional Autónoma de México, Ciudad de \\ México, México. \\ ${ }^{2}$ Department of Geosciences, Texas Tech University, Lubbock, Texas, USA. \\ ${ }^{3}$ Centre for Ocean Climate Chemistry, Institute of Ocean Sciences, Fisheries and Oceans Canada, Sidney, British \\ Columbia, Canada. \\ ${ }^{4}$ Departamento de Recursos del Mar, Centro de Investigación y de Estudios Avanzados del Instituto Politécnico \\ Nacional, 97310 Mérida, Yucatán, México. \\ *Corresponding author; email: luis.ladino@atmosfera.unam.mx
}

Received: June 30, 2020; accepted: October 8, 2020

\begin{abstract}
RESUMEN
Los núcleos de glaciación (INP, por su sigla en inglés) presentes en la atmósfera intervienen en la formación de cristales de hielo, los cuales son indispensables para el desarrollo de precipitación en nubes mixtas. Las fuentes y la composición de los INP son muy variadas: desde el polvo mineral derivado de la erosión de los suelos en los continentes hasta el bioaerosol emitido en la superficie del océano. El dispositivo denominado ensayo de congelación de gotas (DFA) se construyó recientemente para cuantificar la eficiencia de nucleación de hielo en muestras líquidas mediante la congelación por inmersión. Su funcionamiento se validó comparando los resultados con reportes en la literatura y con los análisis de muestras de la microcapa superficial del océano (SML) y de muestras obtenidas a $1 \mathrm{~m}$ de profundidad (BSW) en el Golfo de México (GoM) y en Saanich, frente a la Isla de Vancouver (VI), Canadá. Todas las muestras analizadas contenían INP en concentraciones moderadas, entre $6.0 \times 10^{1}$ y $1.1 \times 10^{5} \mathrm{~L}^{-1}$ de agua, incluso en ausencia de floraciones de fitoplancton. Se estimó la temperatura a la cual se congela el $50 \%$ de las gotas $\left(\mathrm{T}_{50}\right)$ en cada una de las muestras. El valor de $\mathrm{T}_{50}$ fue mayor en muestras de VI SML, seguido por muestras del GoM BSW y del GoM SML, lo que indica que las aguas costeras en latitudes altas tienen un mayor potencial para iniciar la formación de nubes y precipitación.
\end{abstract}

\begin{abstract}
Ice nucleating particles (INPs) in the atmosphere are necessary to generate ice crystals in mixed-phase clouds, a crucial component for precipitation development. The sources and composition of INPs are varied: from mineral dust derived from continental erosion to bioaerosols resulting from bubble bursting at the ocean surface. The performance of a home-built droplet freezing assay (DFA) device for quantifying the ice nucleating abilities of water samples via immersion freezing has been validated against both published results and analyses of samples from sea surface microlayer (SML) and bulk surface water (BSW) from the Gulf of Mexico (GoM) and Saanich Inlet, off Vancouver Island (VI), Canada. Even in the absence of phytoplankton blooms, all the samples contained INPs at moderate concentrations, ranging from $6.0 \times 10^{1}$ to $1.1 \times 10^{5} \mathrm{~L}^{-1}$ water. The freezing temperatures (i.e., $\mathrm{T}_{50}$, the temperature at which $50 \%$ of the droplets freeze) of the samples decreased in order of VI SML $>$ GoM BSW $>$ GoM SML, indicating that the higher-latitude coastal waters have a greater potential to initiate cloud formation and precipitation.
\end{abstract}

Keywords: sea surface microlayer, ice nucleation, Gulf of Mexico, mixed-phase clouds, droplet freezing assay. 


\section{Introduction}

Two thirds of the Earth's surface is covered by oceans, providing a well-known source of aerosol particles that have the potential to nucleate cloud droplets and ice crystals, influencing cloud albedo and precipitation, and hence, climate. Although marine aerosol particles are ubiquitous in the atmosphere, their physical and chemical properties are poorly understood (Bigg and Leck, 2001; Heintzenberg et al., 2004; Gantt and Meskhidze, 2013). The major components of primary marine aerosol are inorganic sea salt and organic matter. The latter can be cellular (e.g., bacteria, phytoplankton, and diatoms) and extracellular (e.g., exopolymeric substances; EPS) (Yoon et al., 2007; Vignati et al., 2010). While organic matter is highly concentrated in the sea surface microlayer (SML), the sea salt content is rather constant for a few meters below the surface. Sea salt particles are injected into the atmosphere together with marine organic matter by sea spray as a result of bubble bursting and wave activity (Facchini et al., 2008; Gantt and Meskhidze, 2013). Vignati et al. (2010) estimated the global sea salt emissions to be $24 \mathrm{Tg}_{\text {year }}{ }^{-1}$, whereas the sub-micron organic matter emissions from sea spray were found to be 8.2 $\mathrm{Tg}$ year $^{-1}$.

Marine aerosol particles can influence mixedphase and cirrus cloud formation because a fraction of them are able to act as ice nucleating particles (INPs), facilitating ice crystal formation via different heterogeneous ice nucleation pathways (e.g., Bigg, 1973; Schnell and Vali, 1975; Schnell, 1975, 1977, 1982; Rosinski et al., 1987, 1988; Mason et al., 2015; DeMott et al., 2016; McCluskey et al., 2017, 2018; Welti et al., 2018; Creamean et al., 2018; Si et al., 2018; Ladino et al., 2019; Gong et al., 2020). As summarized by Burrows et al. (2013), marine microorganisms, EPS aggregates, glassy organics, and crystalline hydrated $\mathrm{NaCl}$ are types of aerosol particles that have the potential to nucleate ice in marine environments. However, whether the marine INPs are dominated by a specific aerosol type, and under what conditions, remains unclear due to the limited number of field and laboratory studies (Kanji et al., 2017).

Recent studies have addressed some of the aforementioned gaps in knowledge. For example, laboratory studies have shown that crystalline salts (e.g., Instant Ocean and $\mathrm{NaCl}$ ), organic matter (e.g., amorphous sucrose), and a variety of marine microorganisms (e.g., Nanochloris atomus, Emiliania huxleyi, Vibrio harveyi, and Prochlorococcus) can efficiently nucleate ice via deposition nucleation at temperatures below $-40{ }^{\circ} \mathrm{C}$ (e.g., Wise et al., 2012; Wagner and Mohler, 2013; Schill and Tolbert, 2014; Ladino et al., 2016; Wolf et al., 2019). At warmer temperatures, Knopf et al. (2011) and Wilson et al. (2015) found that the planktonic diatom species Thalassiosira pseudonana (and their exudates) was able to efficiently nucleate ice via immersion freezing, with freezing temperatures as high as $-23{ }^{\circ} \mathrm{C}$. In mesocosm studies, Wang et al. (2015) and McCluskey et al. (2017) found that the concentration of INPs was significantly enhanced during a phytoplankton bloom. The authors suggest that higher INP concentrations are linked to the presence of heterotrophic bacteria and organic species in the sea spray aerosol. More recently, Tesson and Šantl-Temkiv (2018) found that the marine aquatic microalgae Polarella glacialis was able to nucleate ice via immersion freezing at temperatures close to $-6^{\circ} \mathrm{C}$. As shown by Creamean et al. (2019), biological INPs in the Arctic can be emitted into the atmosphere by marine waters as a result of phytoplankton blooms during summer. In both Arctic (Wilson et al., 2015; Irish et al., 2017) and tropical (Gong et al., 2020) waters, INP concentrations have been observed to be either enriched and depleted in the SML in comparison to bulk surface water (BSW) samples, likely dependent on complex interactions between biological, oceanographic, and meteorological conditions.

Burrows et al. (2013) and Yun and Penner (2013) used global climate models to investigate the potential impacts of marine aerosol on the Earth's radiative balance and the hydrological cycle. Both studies predicted a significant influence of marine organic aerosol (MOA) on cloud properties in the Southern Ocean, remote from terrestrial aerosol sources. In remote areas, MOA could also contribute to the INP concentration significantly where the presence of mineral dust is limited, as is the case for continental biological aerosol (Pratt et al., 2009; Prenni et al., 2009; Pöschl et al., 2010). Recent studies by Wilson et al. (2015), Vergara-Temprado et al. (2017), and McCluskey et al. (2019) reached similar conclusions. 
Burrows et al. (2013) and Yun and Penner (2013) mentioned the urgent need to conduct field studies in marine environments as well as laboratory studies, using marine aerosol particles to reduce uncertainties in global climate predictions. Most notably, there is a limited number of experimental studies focusing on INPs from airborne particles and SML waters in tropical latitudes. Therefore, the currently available parametrizations to model marine INPs may underestimate the role that marine tropical oceans play in the global distribution of INPs.

With the aim to contribute to the understanding of the ice nucleating properties of the marine aerosol in tropical latitudes, a device to quantify the ice nucleating abilities from different types of aerosol samples has been constructed by the Micro and Mesoscale Interactions Group at the Instituto de Ciencias de la Atmósfera y Cambio Climático of the Universidad Nacional Autónoma de México (UNAM). Samples collected from the SML and BSW in the Gulf of Mexico (GoM) and Saanich Inlet (Vancouver Island, Canada), were analyzed using the new device.

\section{Methods}

\subsection{Sampling locations}

Two different sampling locations were chosen for this study: (i) Saanich Inlet, off Vancouver Island (VI), Canada; and (ii) the southern GoM. Sampling at VI took place in Patricia Bay $\left(48^{\circ} 39^{\prime} \mathrm{N}, 123^{\circ} 28^{\prime} \mathrm{W}\right)$ as shown in Figure 1a. SML samples (ca. $25 \mathrm{~mL}$ ) were collected on two different days (March 21 and 22, 2018) and at three different stations using a glass plate (section 2.2). The sampling locations (A, B, and C in Fig. 1a) were approximately $1 \mathrm{~km}$ apart, with location $\mathrm{A}$ about $1 \mathrm{~km}$ from the dock at the Institute of Ocean Sciences. The samples were collected in triplicate and kept frozen (ca. $-4{ }^{\circ} \mathrm{C}$ ) while transported from Canada to Mexico.

Sampling in the GoM took place at Dzilam de Bravo $\left(21^{\circ} 23^{\prime} \mathrm{N}, 88^{\circ} 52^{\prime} \mathrm{W}\right)$ on the Yucatan Peninsula (Fig. 1b) as part of the African Dust and Biomass Burning Over Yucatan (ADABBOY) project. Dzilam de Bravo is $107 \mathrm{~km}$ away from Merida (the capital and most populated city in the Yucatan state) and $79 \mathrm{~km}$ from Progreso (one of the largest harbors in the state). Samples from the SML and BSW were collected (in triplicate) on April 17, 2018 at 10 different stations, separated by $1 \mathrm{~km}$ as shown in Figure 1b. A cold front

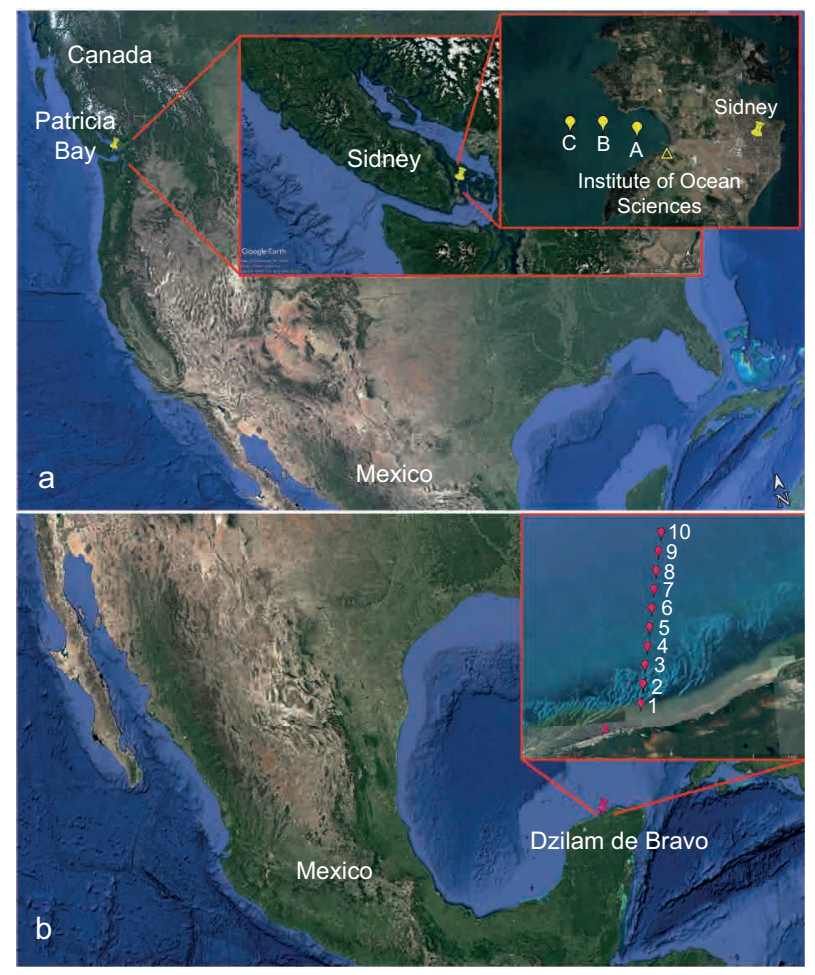

Fig. 1. Sampling sites: (a) at Saanich Inlet, Vancouver Island (VI), and (b) Dzilam de Bravo, Gulf of Mexico (GoM) (Google Earth, 2019). At both locations, individual stations were separated by approximately $1 \mathrm{~km}$.

affected the region on April 17, and therefore wave activity was significant in comparison to previous days and also in comparison to conditions in the protected bay off VI. The samples were kept frozen (ca. $-4{ }^{\circ} \mathrm{C}$ ) while transported to Mexico City.

A total of 48 SML and 10 BSW samples were collected as summarized in Table I. At each sampling station, both at VI and in the GoM, the sea surface temperature (SST), and the salinity were measured with a YSI 85 multiparameter probe.

Table I. Summary of the SML and BSW samples collected in the Gulf of Mexico and off Vancouver Island.

\begin{tabular}{ccc}
\hline \multicolumn{2}{c}{ Collected samples } \\
\hline Gulf of Mexico & Vancouver Island \\
\hline SML: 30 & BSW: 10 & SML: 18 \\
\hline
\end{tabular}




\subsection{Sampling methods}

A glass plate, an old and simple but very useful tool to collect SML samples, was used in this study (Harvey and Burzell, 1972; Cunliffe and Wurl, 2014). We used a $30 \times 20 \mathrm{~cm}$ plate of tempered glass with a thickness of $4 \mathrm{~mm}$ (Fig. 2a). To collect a sample from the SML, the glass plate (previously rinsed at least three times with deionized water on both sides) was vertically immersed into the sea surface and then lifted slowly at a constant rate (Cunliffe and Wurl, 2014). As the glass plate was lifted, the SML adhered to it, so it was removed from the glass plate with the help of a neoprene squeegee as shown in Figure 2b. The SML samples were collected in high-density polyethylene (HDPE) amber bottles and stored at $-20{ }^{\circ} \mathrm{C}$ prior to their analysis. Note that the temperature of the samples was $-4{ }^{\circ} \mathrm{C}$ during their transport to Mexico City, where the DFA analysis were performed. The thickness of the collected SML ( $h$ in $\mathrm{mm}$ ) can be calculated following Eq. (1) from Cunliffe and Wurl (2014):

$h=10^{4} \frac{V}{A \cdot N}$

where $V$ is the sample volume in $\mathrm{cm}^{3}, A$ the total area of the immersed glass plate in $\mathrm{cm}^{2}$ (i.e., the area of both sides), and $N$ the number of dips per sample (dimensionless). BSW samples were only collected in the GoM (Fig. 2c) at a depth of approximately $1 \mathrm{~m}$ using a Niskin bottle (Seabird Coastal).
2.3 The UNAM-droplet freezing assay (UNAMDFA)

The droplet freezing assay (DFA) has been widely used to study the ice nucleating abilities of different aerosol types (Vali and Stansbury, 1966; Vali, 1971; Lindow, 1983; Conen et al., 2011; Attard et al., 2012; Wright and Petters, 2013; Stopelli et al., 2014; Hill et al., 2014; Budke and Koop, 2015; Whale et al., 2015; David et al., 2019). This method specifically studies the immersion freezing mode, which has been recognized as the most important pathway to form ice crystals in mixed-phase clouds (Murray et al., 2012). Ice formation via immersion freezing occurs when a liquid droplet with an aerosol immersed is exposed to decreasing temperatures. As a consequence of the lower temperature, an ice germ forms at the surface of the aerosol particle causing the droplet to freeze (Murray et al., 2012; Kanji et al., 2017). The UNAM-DFA (Fig. 3) is based on the design by David et al. (2019) and consists of: (i) a thermostat (LAUDA PRO-RP 1090) filled with polydimethylsiloxane as recirculating-cooling liquid; (ii) an aluminum sample holder to support the V-bottom Enzyme-Linked Immunosorbent Assay (ELISA) plate (Corning 3896); (iii) a light-emitting diode (LED) system, and (iv) a video camera (ATVIO, HD 1080P, WDV800SA) to record the freezing experiments.

Using an eight-tip micropipette (EPPENDORF 300), $50 \mu \mathrm{L}$ of sample (i.e., SML or BSW) were transferred into each of the 96 wells of a sterile

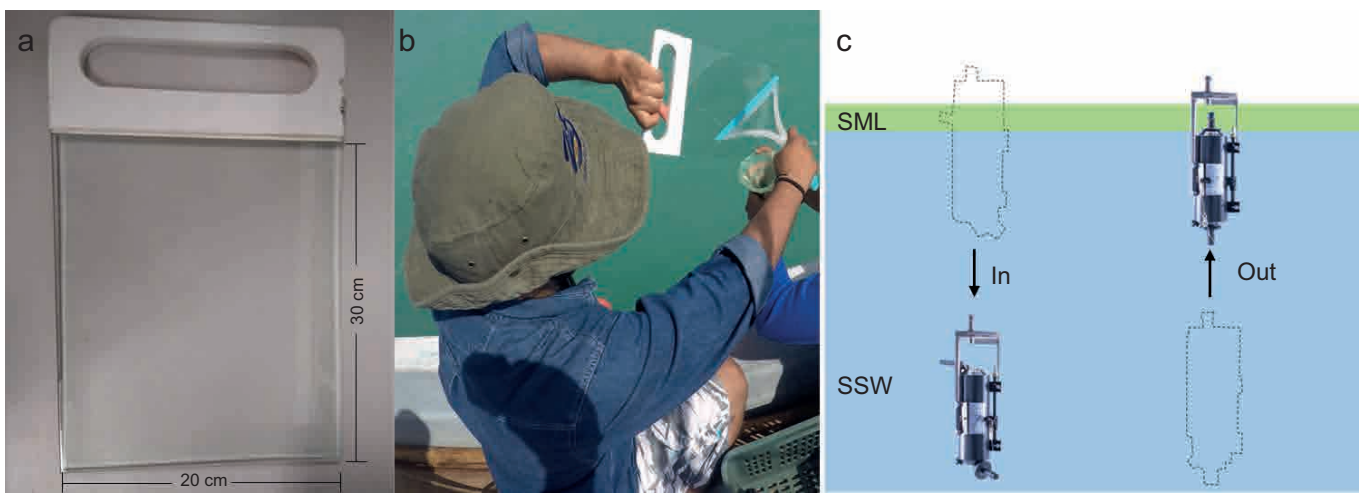

Fig. 2. (a) Glass plate used in the present study, (b) sea surface microlayer (SML) sample collection procedure, and (c) bulk surface water (BSW) sample collection procedure. 
(a)

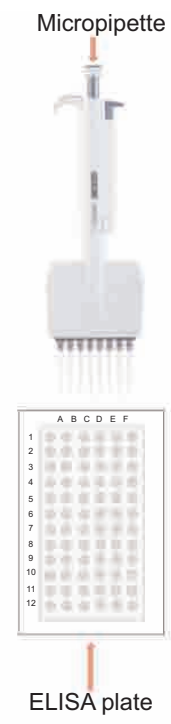

(b)

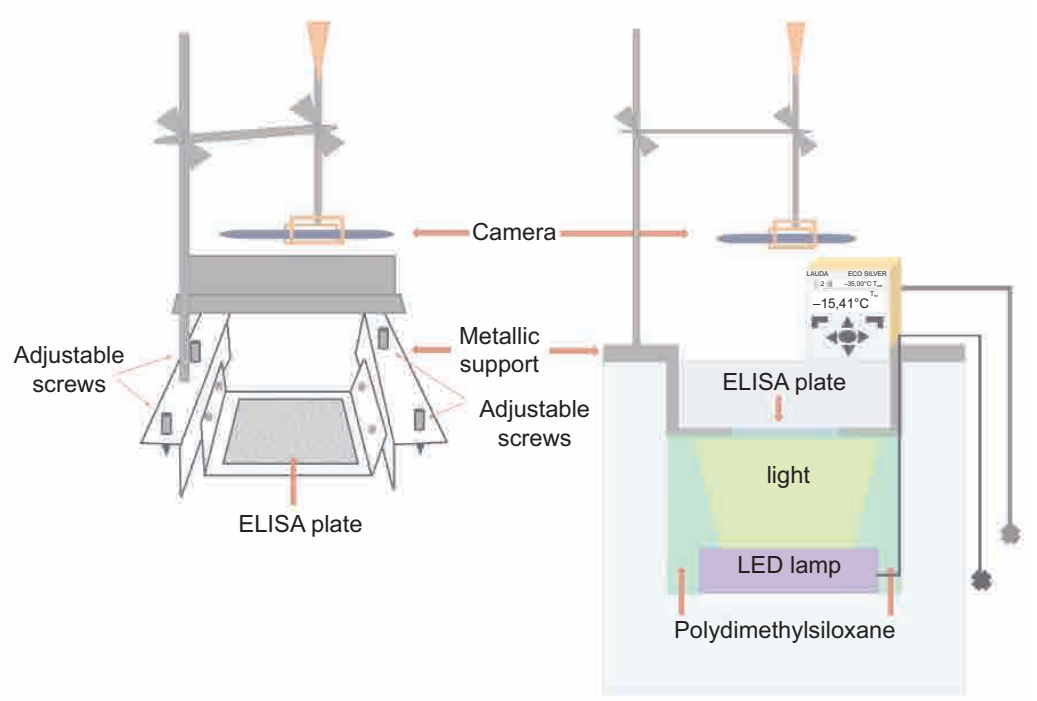

Cooling bath

(LAUDA, PRO RP 1090) (c)

(c)

Fig. 3. Diagram showing the main components of the UNAM-droplet freezing assay (UNAM-DFA). (a) Sample preparation; (b) sample holder, Enzyme-Linked Immunosorbent Assay (ELISA) plate, video camera arrangement, and (c) cross section view of the full setup.

ELISA plate (Fig. 3a). The plate was then covered with a transparent film to seal the plate and to avoid any interaction between the sample and the ambient laboratory air. The $50 \mu \mathrm{L}$ in each well corresponds to the volume of a liquid drop with a diameter of ca. $4.4 \mathrm{~mm}$. The loaded ELISA plate was placed into the cooling bath where the temperature decreased from 0 to $-40^{\circ} \mathrm{C}$ at a cooling rate of $2.66^{\circ} \mathrm{C} \mathrm{min}^{-1}$ (Fig. $3 \mathrm{c}$ ). While the temperature decreased, the freezing of each well was monitored and recorded with the video camera. The freezing of each well was determined by the change in its opacity while transitioning from liquid to solid (Fig. 4). The temperature was assumed to be the same in all of the 96 wells at a given time during the temperature ramp and was recorded from the thermostat with an uncertainty of $\pm 0.01{ }^{\circ} \mathrm{C}$. Given that the volume of the polydimethylsiloxane decreases as a function of temperature due to thermal contraction, the depth of the ELISA plates was manually controlled with the help of adjustable screws on either side of the metallic support (Fig. 3b).

A video and a file of the temperature as a function of time were obtained from each experiment. The frozen fraction $(f)$ at $1{ }^{\circ} \mathrm{C}$ intervals was obtained

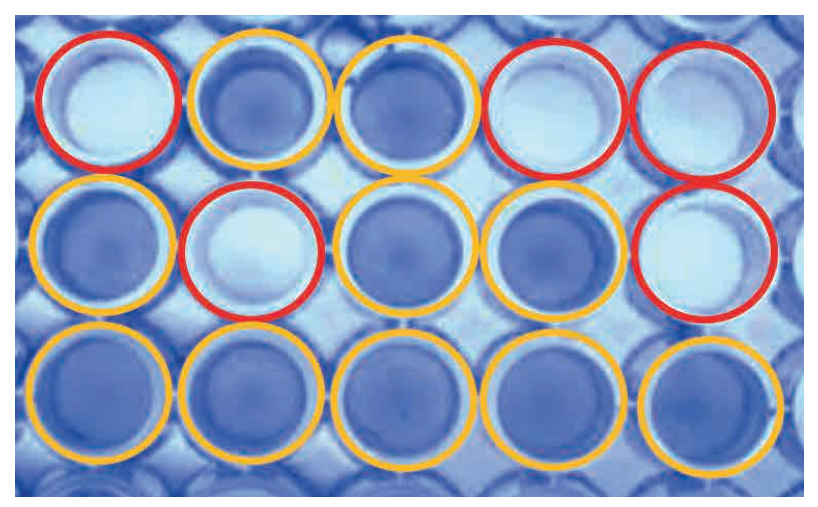

Fig. 4. Example of an Enzyme-Linked Immunosorbent Assay (ELISA) plate with liquid (red circles) and frozen (yellow circles) wells differentiated according to their appearance.

combining both information sources following Eq. (2):

$f=\frac{N_{f}}{N}$

where $N_{\mathrm{f}}$ is the number of frozen droplets at a specific temperature and $N$ the total droplets of the ELISA 
plate (i.e., 96). The cumulative INP concentration $\left(\mathrm{L}^{-1}\right)$ is derived following Eq. (3) (Yadav et al., 2019):

$$
C_{I N P}(T)=\frac{-\ln \left(F_{u f}\right)}{V_{\text {drop }}}
$$

where $F_{\text {uf }}$ is the fraction of unfrozen droplets (dimensionless) at temperature $\mathrm{T}\left({ }^{\circ} \mathrm{C}\right)$, and $V_{\text {drop }}$ is the drop volume (L).

\section{Results and discussion}

\subsection{UNAM-DFA performance}

We performed homogeneous freezing experiments with MilliQ water $(18.2 \mathrm{M} \Omega \mathrm{cm})$ to assess the performance and limits of the UNAM-DFA. As shown in Figure 5a, the homogeneous freezing curve obtained with the UNAM-DFA is close to the one reported by Tobo (2016). However, the liquid droplets from the present results were found to freeze at lower temperatures than those found in previous studies (e.g., Whale et al., 2015; Irish et al., 2017; Yadav et al., 2019). The variability between the homogeneous freezing curves shown in Figure 5a is not surprising given that the spontaneous freezing of liquid droplets is influenced by its size, the cooling rate, and the details of the method used (i.e., suspended droplets vs. droplets placed on cold stages), among other factors. The homogeneous freezing curve serves as a zero. Any freezing event at higher temperatures is attributed to the presence of impurities, such as aerosol ice nucleating particles (INPs), immersed in the droplets and categorized as heterogeneous freezing.

Arizona Test Dust (ATD) was utilized in a secondary experiment to further assess the performance of the UNAM-DFA. ATD can be considered a proxy for natural mineral dust and its ice nucleating abilities in different ice nucleation modes are well known (Kanji et al., 2008; Kanji and Abbatt, 2010; Welti et al., 2009; DeMott et al., 2011; Niemand et al., 2012; Hader et al., 2014; Steinke et al., 2015; Yadav et al., 2019). An aqueous solution of $0.1 \% \mathrm{w} / \mathrm{w}$ ATD (ISO 12103-1; Powder Technology, Inc; A1 ultrafine) in MilliQ water was prepared and analyzed in the UNAM-DFA. Figure 5b shows the relationship between INP concentration (in the form of ATD particles) and freezing temperature. Although the INP concentrations in our samples were lower than those observed by Yadav et al. (2019), the trend with freezing temperature in both data sets is consistent. The small difference found in the concentration range where these two studies overlap can be attributed to the grain size of the ATD, i.e., ultrafine (A1) in the present study versus coarse (A4) used by Yadav et al. (2019).
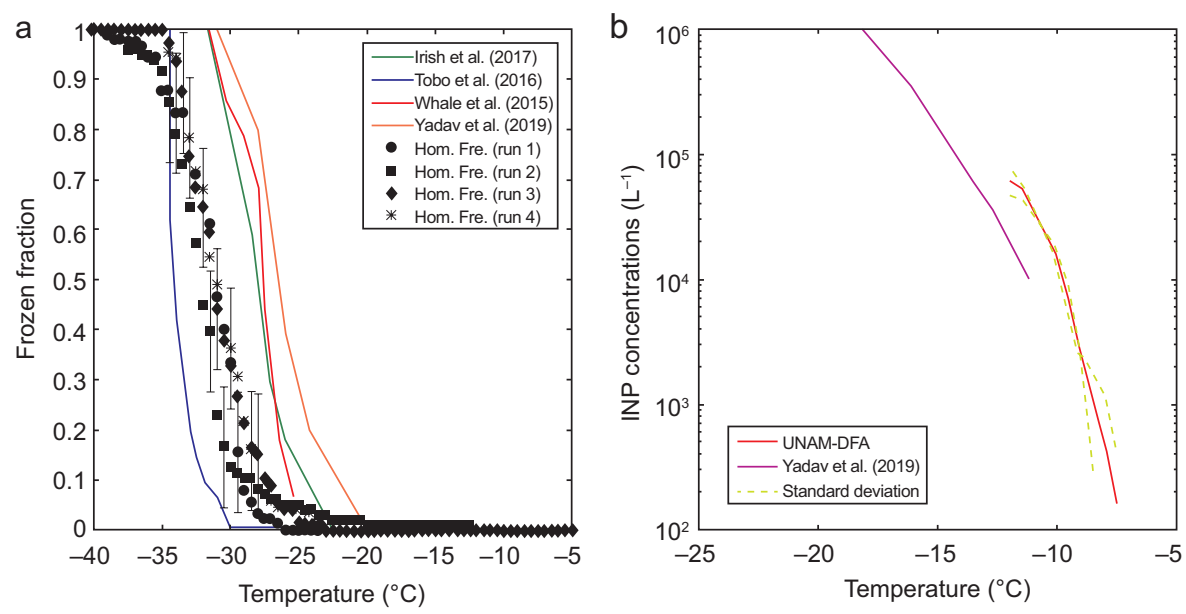

Fig. 5. (a) Homogeneous freezing activation curves, and (b) ice nucleating particles (INP) concentration calculated for Arizona Test Dust (ATD) samples. The error bars are the representative average variability associated to the homogeneous freezing experiments. 


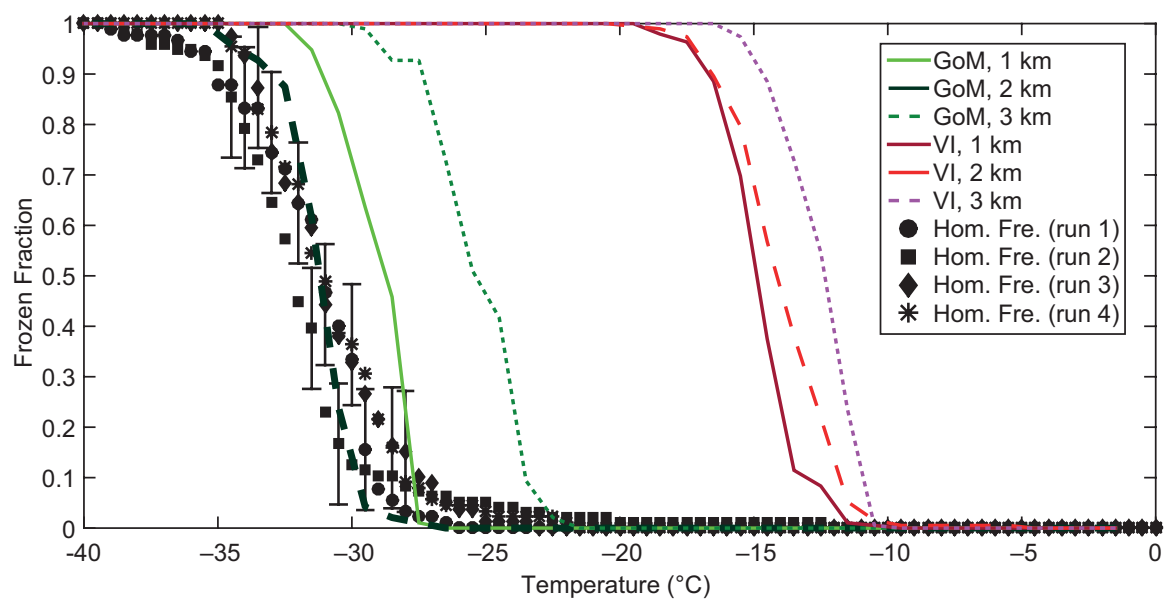

Fig. 6. Frozen fraction curves for the sea surface microlayer (SML) samples collected in the Gulf of Mexico (greenish lines) and off Vancouver Island (reddish lines). The black symbols denote the homogeneous freezing curves, and the error bars are the representative average variability (Fig. 5).

\subsection{Ice nucleating properties of the SML: Gulf of} Mexico vs. Vancouver Island

Figure 6 shows an intercomparison of the frozen fraction of the SML samples collected off VI and in the GoM within $3 \mathrm{~km}$ of shore. The two sets of samples are clearly distinguishable, with the GoM samples closer to the homogeneous freezing line. Therefore, the SML samples from VI were more efficient at nucleating ice. Note that the variability between stations in the ice nucleating abilities of the SML samples from the GoM is greater than those from VI. While the activation curves of the VI samples range from -9.5 to $-18.5^{\circ} \mathrm{C}$, the GoM samples vary from -21.5 to $-35.5^{\circ} \mathrm{C}$. This is consistent with the VI stations being confined to a relatively enclosed inlet, whereas the GoM stations extended more directly away from the coast into open water.

Another way to quantify the ice nucleating ability of a given sample is by the temperature at which $50 \%$ of the droplets freeze, denoted as $\mathrm{T}_{50}$. Figure $7 \mathrm{a}$ shows that the median $\mathrm{T}_{50}$ values for the VI and $\mathrm{GoM}$ SML samples were -13.5 and $-28.7^{\circ} \mathrm{C}$, respectively. Therefore, both the activation scans and the $\mathrm{T}_{50}$ clearly show that the SML samples from VI were significantly more efficient at nucleating ice than those collected in the GoM.

Given that the same person collected the samples and that the instrumentation used to collect the samples and to analyze them were identical, the differences observed in the results are likely related to the different characteristics of the composition of the SML in the GoM and the mid-latitude Saanich Inlet. Table II shows that the average salinity and sea surface temperature (SST) measured in the GoM are significantly higher than those measured at VI. The lower salinity in the waters off VI is a direct result of the high volumes of river waters delivered to the ocean in that area. Irish et al. (2019) also found higher INP concentrations associated with riverine waters in the Arctic Ocean. While crystalline sea salt particles are very inefficient INPs, via immersion freezing, due to their high solubility (e.g., Kanji et al., 2017), organic aerosol particles of marine origin have been shown to be efficient INPs (e.g., Schnell, 1975; Wilson et al., 2015; DeMott et al., 2016; Irish et al., 2017; Creamean et al., 2018; Gong et al., 2020). Van de Poll et al. (2013) showed how lower SST values positively correlate with the availability of nutrients required for marine production. They found that lower SST values are linked with higher chlorophyll-a. Figure 7 shows that the $T_{50}$ values in our samples were inversely related to the SST measured at each sampling site.

\subsection{Ice nucleating capacity of the Gulf of Mexico samples: $S M L$ vs. $B S W$}

Given that SML and BSW samples were collected at each of the 10 sampling stations in the GoM, it was 

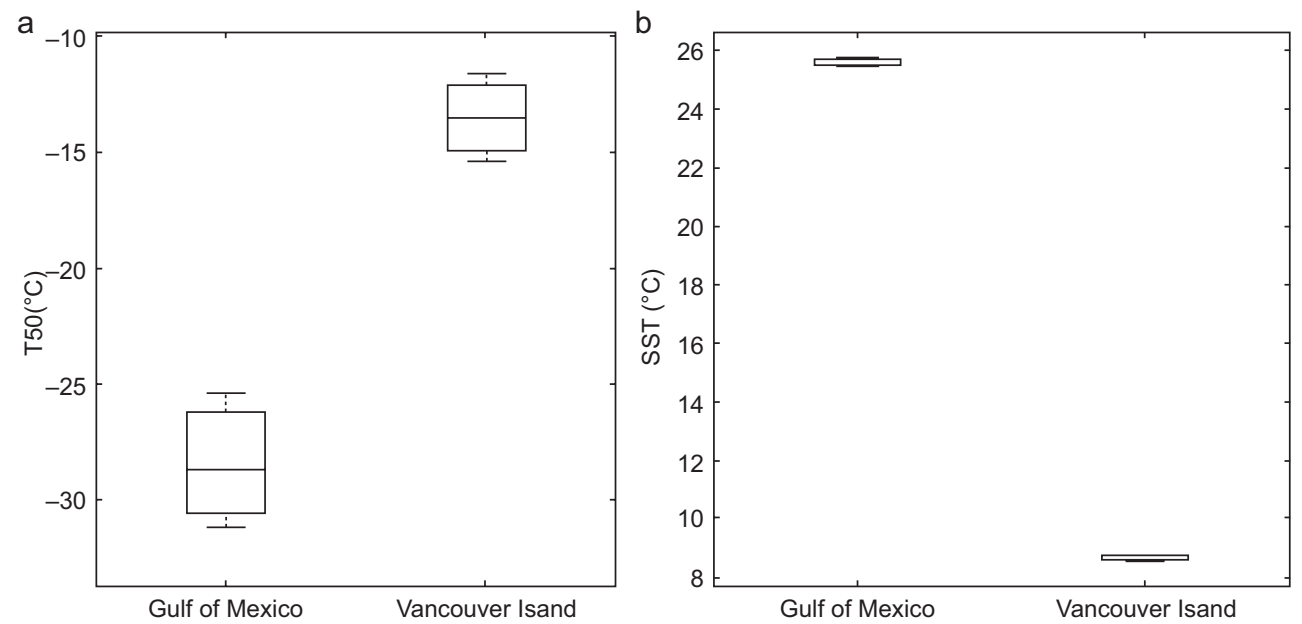

Fig. 7. Box plots for (a) $T_{50}$ values of the Gulf of Mexico (GoM) and Vancouver Island (VI) sea surface microlayer (SML) samples within $3 \mathrm{~km}$ of shore, and (b) the sea surface temperature (SST) measured in the GoM and off VI. Ten GoM and six VI observations were used to build each panel. The top and bottom limits of each box are the 25th and 75th percentiles of the samples, respectively. The median of the samples is represented by the line in the middle of each box. The top and bottom whiskers on each box indicate the maximum and minimum values, respectively.

Table II. Summary of the average physicochemical characteristics of the samples collected* in the Gulf of Mexico (GoM) and off Vancouver Island (VI).

\begin{tabular}{lcccrcc}
\hline Variable & GoM & SD & $\begin{array}{c}\text { Number of } \\
\text { measurements }\end{array}$ & VI & SD & $\begin{array}{c}\text { Number of } \\
\text { measurements }\end{array}$ \\
\hline Sea Surface temperature $\left({ }^{\circ} \mathrm{C}\right)$ & 25.88 & 0.03 & 10 & 8.74 & 0.05 & 6 \\
Salinity (psu) & 34.25 & 7.39 & 10 & 27.94 & 0.13 & 6 \\
\hline
\end{tabular}

SD; standard deviation.

*Samples from both sites were collected during the local morning.

possible to conduct a direct comparison of the ice nucleating abilities of these two types of samples. Figure 8a shows that the BSW samples were more efficient at nucleating ice as their freezing temperatures are closer to $0{ }^{\circ} \mathrm{C}$. This is also shown by the $\mathrm{T}_{50}$ values, where the BSW samples had higher $\mathrm{T}_{50}$ values than the SML samples by $4.2^{\circ} \mathrm{C}$ (Fig. 8b).

Although the present results are in agreement with those reported by Irish et al. (2017) from SML and BSW samples collected in the Arctic, Wilson et al. (2015), Chance et al. (2018), Irish et al. (2019), and Zeppenfeld et al. (2019) found higher ice nucleation efficiencies in the SML in comparison to deeper waters. More recently, Gong et al. (2020) reported the absence of a clear trend between the INP concentrations in the SML and BSW samples collected off Cape Verde, in the Atlantic Ocean (at 16-24 N). Organic matter and hence INPs can be concentrated in the SML. As mentioned above, during the sampling in the GoM a cold front affected the region. This caused the generation of medium to strong waves, which can enhance organic matter enrichment in the SML (Cunliffe et al., 2013). Additionally, as highlighted by Irish et al. (2017) and Wurl and Obbard (2004), the SML sampling method can play an important role in the thickness of the collected SML and therefore in its observed physicochemical properties. Note that in Irish et al. (2017) and in the present study, a glass 

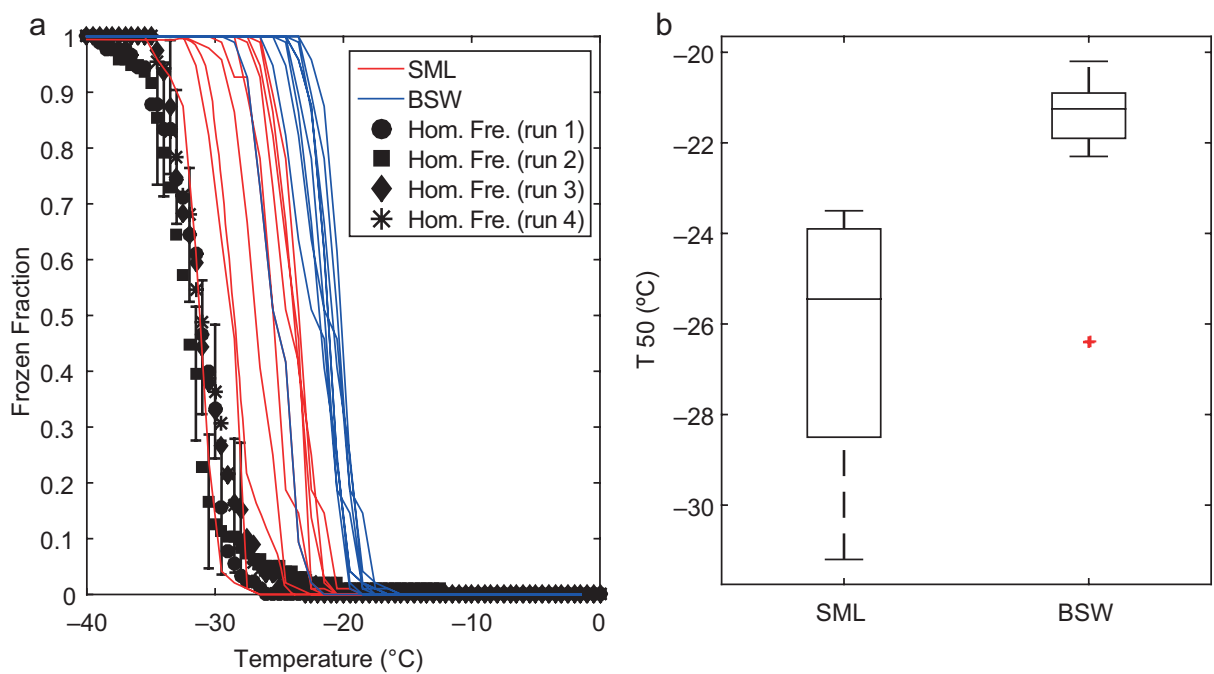

Fig. 8. a) Frozen fraction curves for the sea surface microlayer (SML; red lines) and bulk surface water (BSW; blue lines) samples collected at the Gulf of Mexico, and (b) box plot of the $T_{50}$ from the SML and BSW. The error bars in (a) are the representative average variability associated to the homogeneous freezing experiments. On panel (b), the tops and bottoms of each box are the 25th and 75th percentiles of the samples, respectively. The median of the samples is represented by the line in the middle of each box. The top and bottom whiskers on each box indicate the maximum and minimum values, respectively. The red cross indicates an outlier value.

plate was used to collect the SML. On the other hand, Wilson et al. (2015), Chance et al. (2018), and Irish et al. (2019) used a rotating drum. Overall, there is a hint that the sampling method and hence the thickness of the sampled SML can impact the measured ice nucleating activity. This potential bias deserves further study.

\subsection{Small-scale spatial variability in ice nucleating activity}

The ice nucleating activity of the SML and BSW samples collected in the GoM was evaluated as a function of the distance from shore, as shown in Figure 9. The minimum $\mathrm{T}_{50}$ was observed $2 \mathrm{~km}$ from shore for both the SML and SBW samples. Beyond $3 \mathrm{~km}$, the $\mathrm{T}_{50}$ values for the $\mathrm{BSW}$ were relatively constant $\left(-21.2 \pm 0.7{ }^{\circ} \mathrm{C}\right)$; however, the SML samples showed a higher variability $\left(-25.2 \pm 1.7^{\circ} \mathrm{C}\right)$. Therefore, although a small effect of the coast on the ice nucleating abilities of the SML and BSW waters was observed, this seems to be very local and likely caused by different anthropogenic activities at the coast (e.g., the presence of boats). Although the

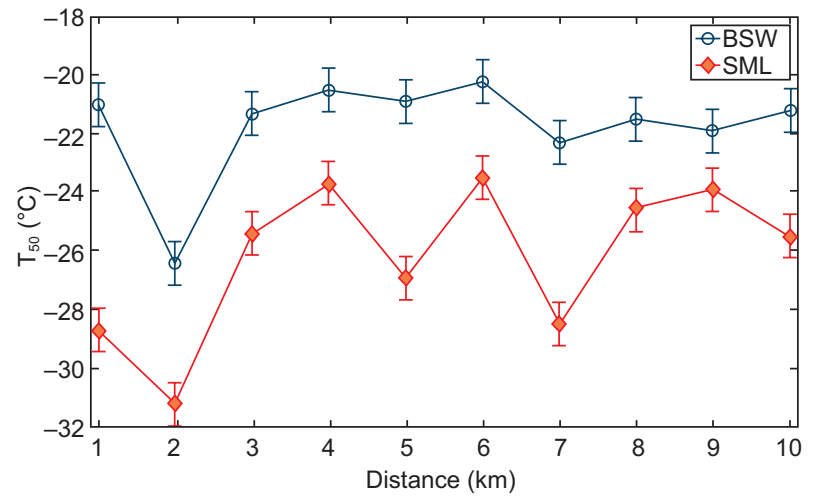

Fig. 9. $\mathrm{T}_{50}$ values as a function of the distance from shore for the sea surface microlayer (SML) and bulk surface water (BSW) samples collected in the Gulf of Mexico. The error bars depict the representative average variability.

$\mathrm{T}_{50}$ values from the BSW samples and the distance from the shore did not correlate $(r=0.25, p=0.48)$, the $\mathrm{T}_{50}$ values from the SML sample were found to moderately correlate with the distance from the shore $(\mathrm{r}=0.52)$; however, the correlation is not statistically significant $(p=0.11)$. It was found that the $T_{50}$ values 
of the SML and BSW, as a function of the distance from the shore, have a good correlation $(r=074, p<$ 0.05 ). This indicates that the properties of the SML and BSW from the GoM may be driven by similar processes such as water mass characteristics (i.e., freshwater fractions) and ecosystem structure.

Although the small-scale (i.e., $10 \mathrm{~km}$ ) spatial distribution of the INPs around Dzilam de Bravo is not constant, the observed variability is not very large. As shown by Wilson et al. (2015) and Irish et al. (2017), significant changes can be found when samples are collected over large distances, much larger than $10 \mathrm{~km}$.

\subsection{INP concentrations}

Using the frozen fractions shown in Figures 6 and $8 \mathrm{a}$ and following Eq. (3), the INP concentrations for the entire data set were calculated and are shown in Figure 10. Although the INP concentrations of the VI and the GoM samples are on the same order of magnitude, the INP activities in the VI samples were found at much higher temperatures than those of the GoM samples. The INP concentrations in the VI SML samples varied from $2.1 \times 10^{2}$ to $9.1 \times 10^{4} \mathrm{~L}^{-1}$ water at temperatures ranging from -10.5 to $-18.5^{\circ} \mathrm{C}$.

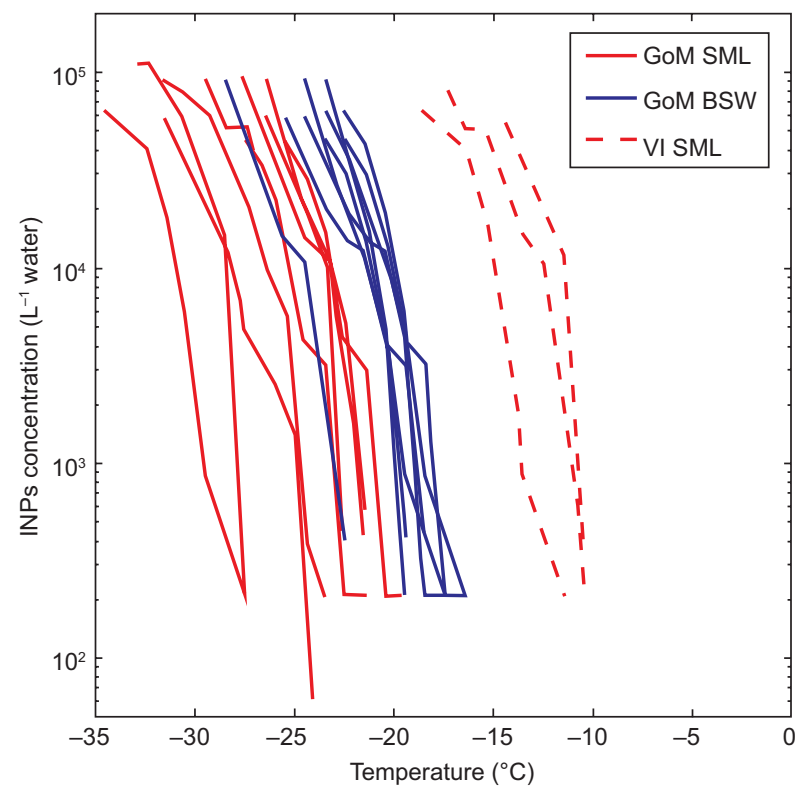

Fig. 10. Ice nucleating particles (INP) concentrations as a function of temperature for the Gulf of Mexico (GoM) and Vancouver Island (VI) samples.
Likewise, the SML and BSW samples from the GoM contained INPs in concentrations from $6.0 \times$ $10^{1}$ to $1.1 \times 10^{5} \mathrm{~L}^{-1}$ water at temperatures below $-16.5^{\circ} \mathrm{C}$. Although the INP concentrations from the VI samples are in agreement with those reported by Wilson et al. (2015) and Irish et al. (2017), the INP concentrations from the GoM samples are two or three orders of magnitude lower, possibly because of the lower overall biological productivity of tropical versus polar and subpolar waters.

\section{Conclusions}

A droplet freezing assay device, denoted as UNAM-DFA, was built at the Universidad Nacional Autónoma de México to study mixed-phase cloud formation via the immersion freezing mode. The results obtained with the UNAM-DFA are in agreement with those reported by similar DFAs built elsewhere. Given the current lack of data on the ice nucleating abilities of aerosol particles emitted in tropical latitudes, the UNAM-DFA will be very useful to fill the gaps in the current knowledge of how the oceanic emissions may impact atmospheric chemistry and cloud formation.

Samples from the sea-surface microlayer of the GoM were found to be less efficient (lower $\mathrm{T}_{0}$ and $\mathrm{T}_{50}$ values by $12^{\circ} \mathrm{C}$ and $15^{\circ} \mathrm{C}$, respectively) at nucleating ice than comparable samples collected off VI, on the west coast of Canada. This is likely related to the physicochemical characteristics, including freshwater influences and overall biological productivity, of the GoM and VI waters. Given that neither the GoM nor the VI samples were collected under the influence of coincident phytoplankton blooms, it would be interesting to collect samples during active blooms in the GoM (i.e., October-November) to assess whether the ice nucleating abilities of the SML are higher under such conditions than those observed here.

The bulk surface waters from the GoM were found to have higher ice nucleating activities than the corresponding SML samples, as the $\mathrm{T}_{50}$ values in the bulk waters were $4.2^{\circ} \mathrm{C}$ higher. Although this can be considered somewhat unusual, similar results have also been found in the high Arctic (Irish et al., 2017). The conditions and processes that lead to enrichment of ice-nucleating activity in the sea-surface microlayer deserve further investigation. 
For the most part, there was not a clear pattern in the spatial distribution of ice nucleating activity of the SML and BSW samples either in the GoM or off VI. However, more information is required to assess possible causes of the minimum $T_{50}$ values found $2 \mathrm{~km}$ from shore in the GoM. The good correlation between the $\mathrm{SML} \mathrm{T}_{50}$ and $\mathrm{BSW} \mathrm{T}_{50}$ as a function of the distance from the shore suggests that the properties of both types of samples may be driven by similar processes such as water mass characteristics (i.e., freshwater fractions) and ecosystem structure. It would be interesting to collect SML and BSW samples out in the open Pacific Ocean and further into the central GoM to evaluate whether their ice nucleating abilities differ significantly from those found closer to shore.

Finally, the INP concentrations in the GoM $(6.0 \times$ $10^{1}$ to $1.1 \times 10^{5} \mathrm{~L}^{-1}$ water $)$ and VI $\left(2.1 \times 10^{2}\right.$ to 9.1 $\times 10^{4} \mathrm{~L}^{-1}$ water) samples agreed well with literature data at different locations, with the exception of the SML samples from the GoM, which were substantially lower than other observations. The high INP concentrations found at high temperatures in the VI samples suggest that these waters have the potential to significantly affect mixed-phase cloud formation on a local scale.

\section{Acknowledgments}

The authors thank W. Gutierrez†, M. García, A. Rodríguez, E. Salinas, and L. Martínez for their invaluable help. This study was financially supported by DGAPA (Dirección General de Asuntos del Personal Académico) and CONACYT (Consejo Nacional de Ciencia y Tecnología) through grants PAPIIT IA108417, PAPIIT IN111120, and FC-2164, respectively, and by Fisheries and Oceans Canada.

\section{References}

Attard E, Yang H, Delort A-M, Amato P, Pöschl U, Glaux

C, Koop T, Morris CE. 2012. Effects of atmospheric conditions on ice nucleation activity of Pseudomonas. Atmospheric Chemistry and Physics 12: 10667-10677. https://doi.org/10.5194/acp-12-10667-2012

Bigg EK. 1973. Ice nucleus concentrations in remote areas. Journal of the Atmospheric Sciences 30: 1153-1157. https://doi.org/10.1175/1520-0469(1973)030<1153 :INCIRA $>2.0 . \mathrm{CO} ; 2$
Bigg EK, Leck C. 2001. Cloud-active particles over the central Arctic Ocean. Journal of Geophysical Research 106: 32,155-32,166. https://doi.org/10.1029/ 1999JD901152

Budke C, Koop T. 2015. BINARY: An optical freezing array for assessing temperature and time dependence of heterogeneous ice nucleation. Atmospheric Measurements Techniques 8: 689-703. https://doi.org/10.5194/ amt-8-689-2015

Burrows SM, Hoose C, Pöschl U, Lawrence MG. 2013. Ice nuclei in marine air: Biogenic particles or dust? Atmospheric Chemistry and Physics 13: 245-267. https://doi.org/10.5194/acp-13-245-2013

Chance RJ, Hamilton JF, Carpenter LJ, Hackenberg SC, Andrews SJ, Wilson TW. 2018. Water-soluble organic composition of the arctic sea surface microlayer and association with ice nucleation ability. Environmental Science and Technology 52: 1817-1826. https://doi. org/10.1021/acs.est.7b04072

Conen F, Morris CE, Leifeld J, Yakutin MV, Alewell C. 2011. Biological residues define the ice nucleation properties of soil dust. Atmospheric Chemistry and Physics 11: 9643-9648. https://doi.org/10.5194/acp-11-9643-2011

Creamean JM, Kirpes RM, Pratt KA, Spada NJ, Maahn M, de Boer G, Schnell RC, China S. 2018. Marine and terrestrial influences on ice nucleating particles during continuous springtime measurements in an Arctic oilfield location. Atmospheric Chemistry and Physics 18: 18023-18042. https://doi.org/10.5194/ acp-18-18023-2018

Creamean JM, Cross JN, Pickart R, McRaven L, Lin P, Pacini A, Hanlon R, Schmale DG, Ceniceros J, Aydell T, Colombi N, Bolger E, DeMott PJ. 2019. Ice nucleating particles carried from below a phytoplankton bloom to the Arctic atmosphere. Geophysical Research Letters 46: 8572-8581. https://doi. org/10.1029/2019GL083039

Cunliffe M, Engel A, Frka S, Gašparović B, Guitart C, Murrell JC, Salter M, Stolle C, Upstill-Goddard R, Wurl O. 2013. Sea surface microlayers: A unified physicochemical and biological perspective of the air-ocean interface. Progress in Oceanography 109: 104-16. https://doi.org/10.1016/j.pocean.2012.08.004

Cunliffe M, Wurl O. 2014. Guide to best practices to study the ocean's surface. Occasional Publications of the Marine Biological Association of the United Kingdom, Plymouth, UK, 118 pp. https://doi.org/10.25607/ OBP-1512 
David RO, Cascajo-Castresana M, Brennan KP, Rösch M, Els N, Werz J, Weichlinger V, Boynton LS, Bogler S, Borduas-Dedekind N, Marcolli C, Kanji ZA. 2019. Development of the DRoplet Ice Nuclei Counter Zurich (DRINCZ): Validation and application to field-collected snow samples. Atmospheric Measurement Techniques 12: 6865-6888. https://doi.org/10.5194/ amt-12-6865-2019

DeMott PJ, Möhler O, Stetzer O, Vali G, Levin Z, Petters MD, Murakami M, Leisner T, Bundke U, Klein H, Kanji ZA, Cotton R, Jones H, Benz S, Brinkmann M, Rzesanke D, Saathoff H, Nicolet M, Saito A, Nillius B, Bingemer H, Abbatt J, Ardon K, Ganor E, Georgakopoulos DG, Saunders C. 2011. Resurgence in ice nuclei measurement research. Bulletin of the American Meteorological Society 92: 1623-1635. https://doi. org/10.1175/2011BAMS3119.1

DeMott PJ, Hill TC, McCluskey CS, Prather KA, Collins DB, Sullivan RC, Ruppel MJ, Mason R H, Irish VE, Lee T, Hwang CY, Rhee TS, Snider FR, McMeeking GR, Dhaniyala S, Lewis E, Wentzell JJB, Abbatt J, Lee C, Sultana CM, Ault AP, Axson JL, Diaz Martinez M, Venero I, Santos-Figueroa G, Stoke MD, Deane GB, Mayol-Bracero OL, Grassian VH, Bertram TH, Bertram AK, Moffett BF, Franc GD. 2016. Sea spray aerosol as a unique source of ice nucleating particles. Proceedings of the National Academy of Sciences 113: 5797-5803. https://doi.org/10.1073/pnas.1514034112

Facchini MC, Rinaldi M, Decesari S, Carbone C, Finessi E, Mircea M, Fuzzi S, Ceburnis D, Flanagan R, Nilsson ED, de Leeuw G, Martino M, Woeltjen J, O’Dowd CD. 2008. Primary submicron marine aerosol dominated by insoluble organic colloids and aggregates. Geophysical Research Letters 35: L17814. https://doi. org/10.1029/2008GL034210

Gantt B, Meskhidze N. 2013. The physical and chemical characteristics of marine primary organic aerosol: A review. Atmospheric Chemistry and Physics 13: 3979-3996. https://doi.org/10.5194/acp-13-3979-2013

Gong X, Wex H, van Pinxteren M, Triesch N, Fomba KW, Lubitz J, Stolle C, Robinson T-B, Müller T, Herrmann H, Stratmann F. 2020. Characterization of aerosol particles at Cabo Verde close to sea level and at the cloud level - Part 2: Ice-nucleating particles in air, cloud and seawater. Atmospheric Chemistry and Physics 20: 1451-1468. https://doi.org/10.5194/acp-20-1451-2020

Hader JD, Wright T P, Petters MD. 2014. Contribution of pollen to atmospheric ice nuclei concentrations.
Atmospheric Chemistry and Physics 14: 5433-5449. https://doi.org/10.5194/acp-14-5433-2014

Harvey GW, Burzell LA. 1972. A simple microlayer method for small samples. Limnology and Oceanography 11: 156-157. https://doi.org/10.4319/lo.1972.17.1.0156 Heintzenberg J, Birmili W, Wiedensohler A, Nowak A, Tuch T. 2004. Structure, variability and persistence of the submicrometre marine aerosol. Tellus B 56: 357-367. https://doi.org/10.3402/tellusb.v56i4.16450 Hill TCJ, Moffett BF, DeMott PJ, Georgakopoulos DG, Stump WL, Franc GD. 2014. Measurement of ice nucleation-active bacteria on plants and in precipitation by quantitative PCR. Applied and Environmental Microbiology 80: 1256-1267. https://doi.org/10.1128/ AEM.02967-13

Irish VE, Elizondo P, Chen J, Chou C, Charette J, Lizotte M, Ladino LA, Wilson TW, Gosselin M, Murray BJ, Polishchuk E, Abbatt JPD, Miller LA, Bertram AK. 2017. Ice-nucleating particles in Canadian Arctic sea-surface microlayer and bulk seawater. Atmospheric Chemistry and Physics 17: 10583-10595. https://doi. org/10.5194/acp-17-10583-2017

Irish VE, Hanna SJ, Xi Y, Boyer M, Polishchuk E, Ahmed M, Chen J, Abbatt JPD, Gosselin M, Chang R, Miller LA, Bertram AK. 2019. Revisiting properties and concentrations of ice-nucleating particles in the sea surface microlayer and bulk seawater in the Canadian Arctic during summer. Atmospheric Chemistry and Physics 19: 7775-7787. https://doi.org/10.5194/acp19-7775- 2019

Kanji ZA, Florea O, Abbatt JPD. 2008. Ice formation via deposition nucleation on mineral dust and organics: Dependence of onset relative humidity on total particulate surface area. Environmental Research Letters 3: 025004. https://doi.org/10.1088/1748-9326/3/2/02 5004Kanji ZA, Abbatt JPD. 2010. Ice nucleation onto Arizona test dust at cirrus temperatures: Effect of temperature and aerosol size on onset relative humidity. The Journal of Physical Chemistry A 114: 935-941. https://doi.org/10.1021/jp908661m

Kanji ZA, Ladino LA, Wex H, Boose Y, Burkert-Kohn M, Cziczo DJ, Krämer M. 2017. Overview of ice nucleating particles. Meteorological Monographs 58: 1.1-1.33. https://doi.org/10.1175/AMSMONOGRAPHS-D-16-0006.1

Knopf DA, Alpert PA, Wang B, Aller JY. 2011. Stimulation of ice nucleation by marine diatoms. Nature Geoscience 4: 88-90. https://doi.org/10.1038/ngeo1037 
Ladino LA, Yakobi-Hancock JD, Kilthau WP, Mason RH, Si M, Li J, Miller LA, Schiller CL, Huffman JA, Aller JY, Knopf DA, Betram AK, Abbatt JPD. 2016. Addressing the ice nucleating abilities of marine aerosol: A combination of deposition mode laboratory and field measurements. Atmospheric Environment 132: 1-10. https://doi.org/10.1016/j.atmosenv.2016.02.028

Ladino LA, Raga GB, Álvarez-Ospina H, Andino-Enríquez MA, Rosas I, Martínez L, Salinas E, Miranda J, Ramírez-Díaz Z, Figueroa B, Chou C, Bertram AK, Quintana ET, Maldonado LA, García-Reynoso A, Si M, Irish VE. 2019. Ice nucleating particles in a coastal tropical site. Atmospheric Chemistry and Physics 19: 6147-6165. https://doi.org/10.5194/acp-19-6147-2019

Lindow SE. 1983. The role of bacterial ice nucleation in frost injury to plants. Annual Review of Phytopathology 21: 363-384. https://doi.org/10.1146/annurev. py.21.090183.002051

Mason RH, Si M, Li J, Chou C, Dickie R, Toom-Sauntry D, Pöhlker C, Yakobi-Hancock JD, Ladino LA, Jones K, Leaitch WR, Schiller CL, Abbatt JPD, Huffmann JA, Bertram AK. 2015. Ice nucleating particles at a coastal marine boundary layer site: correlations with aerosol type and meteorological conditions. Atmospheric Chemistry and Physics 15: 12 547-12 566. https://doi. org/10.5194/acp-15-12547-2015

McCluskey CS, Hill TCJ, Malfatti F, Sultana CM, Lee C, Santander MV, Beall CM, Moore KA, Cornwell GC, Collins DB, Prather KA, Jayarathne T, Stone EA, Azam F, Kreidenweis SM, DeMott PJ. 2017. A dynamic link between ice nucleating particles released in nascent sea spray aerosol and oceanic biological activity during two mesocosm experiments. Journal of the Atmospheric Sciences 74: 151-166. https://doi. org/10.1175/JAS-D-16-0087.1

McCluskey CS, Hill TCJ, Humphries RS, Rauker AM, Moreau S, Strutton PG, Chamber SD, Williams AG, McRobert I, Ward J, Keywood MD, Harnwell J, Ponsonby W, Loh ZM, Krummel PB, Protat A, Kreidenweis SM, DeMott PJ. 2018. Observations of ice nucleating particles over Southern Ocean waters. Geophysical Research Letters 45: 11,989-11,997. https://doi.org/10.1029/2018GL079981

McCluskey CS, DeMott PJ, Ma P-L, Burrows SM. 2019. Numerical representations of marine ice-nucleating particles in remote marine environments evaluated against observations. Geophysical Research Letters 46: 7838-7847. https://doi.org/10.1029/2018GL081861
Murray B, O’Sullivan D, Atkinson J, Webb M. 2012. Ice nucleation by particles immersed in supercooled cloud droplets. Chemical Society Reviews 41: 6519-6554, https://doi.org/10.1039/C2CS35200A

Niemand M, Möhler O, Vogel B, Vogel H, Hoose C, Connolly P, Klein H, Bingemer H, DeMott P, Skrotzki J, Leisner T. 2012. A particle-surface-area-based parameterization of immersion freezing on desert dust particles. Journal of the Atmospheric Sciences 69: 3077-3092. https://doi.org/10.1175/JAS-D-11-0249.1

Pöschl U, Martin S, Sinha B, Chen Q, Gunthe S, Huffman J, Borrmann S, Farmer D, Garland R, Helas G, Jiménez JL, King SM, Manzi A, Mikhailov E, Pauliquevis T, Petters MD, Prenni AJ, Roldin P, Rose D, Schneider J, Su H, Zorn SR, Artaxo P, Andreae MO. 2010. Rainforest aerosols as biogenic nuclei of clouds and precipitation in the Amazon. Science 329: 1513-1516. https://doi.org/10.1126/science.1191056

Pratt K, DeMott P, French J, Wang Z, Westphal D, Heymsfield A, Twohy C, Prenni A, Prather K. 2009. In situ detection of biological particles in cloud ice-crystals. Nature Geoscience 2: 398-401. https://doi.org/10.1038/ ngeo521

Prenni A, Petters M, Kreidenweis S, Heald C, Martin S, Artaxo P, Garland R, Wollny A, Pöschl U. 2009. Relative roles of biogenic emissions and Saharan dust as ice nuclei in the Amazon basin. Nature Geoscience 2: 402-405. https://doi.org/10.1038/ngeo517

Rosinski J, Haagenson P, Nagamoto C, Parungo F. 1987. Nature of ice-forming nuclei in marine air masses. Journal of Aerosol Science 18: 291-309. https://doi. org/10.1016/0021-8502(87)90024-3

Rosinski J, Haagenson P, Nagamoto C, Quintana B, Parungo F, Hoyt S. 1988. Ice-forming nuclei in air masses over the Gulf of Mexico. Journal of Aerosol Science 19: 539-551. https://doi.org/10.1016/00218502(88)90206-6

Schill GP, Tolbert MA. 2014. Heterogeneous ice nucleation on simulated sea-spray aerosol using Raman microscopy. The Journal of Physical Chemistry C 118: 29,234-29,241. https://doi.org/10.1021/jp505379j

Schnell RC. 1975. Ice nuclei produced by laboratory cultured marine phytoplankton. Geophysical Research Letters 2: 500-502. https://doi.org/10.1029/ GL002i011p00500

Schnell RC, Vali G. 1975. Freezing nuclei in marine waters. Tellus 27: 321-323. https://doi.org/10.3402/ tellusa.v27i3.9911 
Schnell RC. 1977. Ice nuclei in seawater, fog water and marine air off the coast of Nova Scotia: Summer 1975. Journal of the Atmospheric Sciences 34: 1299-1305. https://doi.org/10.1175/1520-0469(1977)034<1299:I $\mathrm{NISFW}>2.0 . \mathrm{CO} ; 2$

Schnell RC. 1982. Airborne ice nucleus measurements around the Hawaiian Islands. Journal of Geophysical Research 87: 8886-8890. https://doi.org/10.1029/ JC087iC11p08886

Si M, Irish VE, Mason RH, Vergara-Temprado J, Hanna SJ, Ladino LA, Yakobi-Hancock JD, Schiller CL, Wentzell JJB, Abbatt JPD, Carslaw KS, Murray BJ, Bertram AK. 2018. Ice-nucleating ability of aerosol particles and possible sources at three coastal marine sites. Atmospheric Chemistry and Physics 18: 1566915685. https://doi.org/10.5194/acp-18-15669-2018

Steinke I, Hoose C, Möhler O, Connolly P, Leisner T. 2015. A new temperature- and humidity-dependent surface site density approach for deposition ice nucleation. Atmospheric Chemistry and Physics 15: 3703-3717. https://doi.org/10.5194/acp-15-3703-2015

Stopelli E, Conen F, Zimmermann L, Alewell C, Morris CE. 2014. Freezing nucleation apparatus puts new slant on study of biological ice nucleators in precipitation. Atmospheric Measurement Techniques 7: 129-134. https://doi.org/10.5194/amt-7-129-2014

Tesson SVM, Šantl-Temkiv T. 2018. Ice nucleation activity and aeolian dispersal success in airborne and aquatic microalgae. Frontiers in Microbiology 9: 2681. https:// doi.org/10.3389/fmicb.2018.02681

Tobo Y. 2016. An improved approach for measuring immersion freezing in large droplets over a wide temperature range. Scientific Reports 6: 32930. https://doi. org/10.1038/srep32930

Vali G, Stansbury EJ. 1966. Time-dependent characteristics of the heterogeneous nucleation of ice. Canadian Journal of Physics 44: 477-502. https://doi. org/10.1139/p66-044

Vali G. 1971. Quantitative evaluation of experimental results on the heterogeneous freezing nucleation of supercooled liquids. Journal of the Atmospheric Sciences 28: 402-409. https://doi.org/10.1175/1520-046 9(1971)028<0402:QEOERA $>2.0 . C O ; 2$

Van de Poll W, Kulk G, Timmermans K, Brussaard C, Van Der Woerd H, Kehoe M, Mojica K, Visser R, Rozema P, Buma A. 2013. Phytoplankton chlorophyll a biomass, composition, and productivity along a temperature and stratification gradient in the northeast Atlantic
Ocean. Biogeosciences 10: 4227-4240. https://doi. org/10.5194/bg-10-4227-2013

Vergara-Temprado J, Murray BJ, Wilson TW, O’Sullivan D, Browse J, Pringle KJ, Ardon-Dryer K, Bertram AK, Burrows SM, Ceburnis D, DeMott PJ, Mason RH, O’Dowd CD, Rinaldi M, Carslaw KS. 2017. Contribution of feldspar and marine organic aerosols to global ice nucleating particle concentrations. Atmospheric Chemistry and Physics 17: 3637-3658. https://doi. org/10.5194/acp-17-3637-2017

Vignati E, Facchini MC, Rinaldi M, Scannell C, Ceburnis D, Sciare J, Kanakidou M, Myriokefalitakis S, Dentener F, O’Dowd CD. 2010. Global scale emission and distribution of sea-spray aerosol: Sea-salt and organic enrichment. Atmospheric Environment 44: 670-677. https://doi.org/10.1016/j.atmosenv.2009.11.013

Wagner R, Möhler O. 2013. Heterogeneous ice nucleation ability of crystalline sodium chloride dihydrate particles. Journal of Geophysical Research: Atmospheres 118: 4610-4622. https://doi.org/10.1002/jgrd.50325

Wang X, Sultana CM, Trueblood J, Hill TC, Malfatti F, Lee C, Laskina O, Moore KA, Beall CM, McCluskey CS, Cornwell GC, Zhou Y, Cox JL, Pendergraft MA, Santander MV, Bertram TH, Cappa CD, Azam F, DeMott PJ, Grassian VH, Prather KA. 2015. Microbial control of sea spray aerosol composition: a tale of two blooms. ACS Central Science 1: 124-131. https://doi. org/10.1021/acscentsci.5b00148

Welti A, Lüönd F, Stetzer O, Lohmann U. 2009. Influence of particle size on the ice nucleating ability of mineral dusts. Atmospheric Chemistry and Physics 9: 67056715. https://doi.org/10.5194/acp-9-6705-2009

Welti A, Müller K, Fleming ZL, Stratmann F. 2018. Concentration and variability of ice nuclei in the subtropical maritime boundary layer. Atmospheric Chemistry and Physics 18: 5307-5320. https://doi.org/10.5194/ acp-18-5307-2018

Whale TF, Murray BJ, O'Sullivan D, Wilson TW, Umo NS, Baustian KJ, Atkinson JD, Workneh DA, Morris GJ. 2015. A technique for quantifying heterogeneous ice nucleation in microliter supercooled water droplets. Atmospheric Measurement Techniques 8: 2437-2447. https://doi.org/10.5194/amt-8-2437-2015

Wilson TW, Ladino LA, Alpert PA, Breckels MN, Brooks IM, Burrows SM, Carslaw KS, Huffman JA, Judd C, Kilthau WP, Mason RH, McFiggans G, Miller LA, Nájera JJ, Polishchuk E, Rae S, Schiller CL, Si M, Vergara-Temprado J, Whale TF, Wong JPS, Wurl O, 
Yakobi-Hancock JD, Abbatt JPD, Aller JY, Bertram AK, Knopf DA, Murray BJ. 2015. A marine biogenic source of atmospheric ice-nucleating particles. Nature 525: 234. https://doi.org/10.1038/nature14986

Wise ME, Baustian KJ, Koop T, Freedman MA, Jensen EJ, Tolbert MA. 2012. Depositional ice nucleation onto crystalline hydrated $\mathrm{NaCl}$ particles: A new mechanism for ice formation in the troposphere. Atmospheric Chemistry and Physics 12: 1121-1134. https://doi. org/10.5194/acp-12-1121-2012

Wolf MJ, Coe A, Dove LA, Zawadowicz MA, Dooley K, Biller SJ, Zhang Y, Chisholm SW, Cziczo DJ. 2019. Investigating the heterogeneous ice nucleation of sea spray aerosols using Prochlorococcus as a model source of marine organic matter. Environmental Science and Technology 53: 1139-1149. https://doi. org/10.1021/acs.est.8b05150

Wright TP, Petters MD. 2013. The role of time in heterogeneous freezing nucleation. Journal of Geophysical Research: Atmospheres 118: 3731-3743. https://doi. org/10.1002/jgrd.50365

Wurl O, Obbard JP. 2004. A review of pollutants in the sea-surface microlayer (SML): A unique habitat for marine organisms. Marine Pollution Bulletin 48: 10161030. https://doi.org/10.1016/j.marpolbul.2004.03.016

Yadav S, Venezia RE, Paerl RW, Petters MD. 2019. Characterization of ice nucleating particles over Northern India. Journal of Geophysical Research 124: 10,46710,482. https://doi.org/10.1029/2019JD030702

Yoon Y, Ceburnis D, Cavalli F, Jourdan O, Putaud J, Facchini M, Decesari S, Fuzzi S, Sellegri K, Jennings S, O'Dowd CD. 2007. Seasonal characteristics of the physicochemical properties of North Atlantic marine atmospheric aerosols. Journal of Geophysical Research 112: D04206. https://doi.org/10.1029/2005JD007044

Yun Y, Penner JE. 2013. An evaluation of the potential radiative forcing and climatic impact of marine organic aerosols as heterogeneous ice nuclei. Geophysical Research Letters 40: 4121-4126. https://doi.org/10.1002/ grl.50794

Zeppenfeld S, van Pinxteren M, Hartmann M, Bracher A, Stratmann F, Herrmann H. 2019. Glucose as a potential chemical marker for ice nucleating activity in Arctic seawater and melt pond samples. Environmental Science and Technology 53: 8747-8756. https://doi. org/10.1021/acs.est.9b01469 